\title{
Comparison of Antioxidant Properties of Water and Ethanol Extracts Obtained from Dried Boxthorn (Lycium chinensis) Fruit
}

\author{
Joo-Shin Kim ${ }^{1,2}$ \\ ${ }^{1}$ Department of Convergence Industry, Health Industry Program, The Seoul Venture University, Seoul, South Korea; ${ }^{2}$ Kwangil Syn- \\ thesis Plant Co. Ltd., Seoul, South Korea. \\ Email: coffee670@naver.com
}

Received July $24^{\text {th }}, 2012$; revised August $24^{\text {th }}$, accepted September $3^{\text {rd }}, 2012$

\begin{abstract}
Antioxidant activities of $\mathrm{W}$ and $\mathrm{E}$ extracts obtained from dried boxthorn (Lycium chinensis) fruit were measured based on DPPH radical scavenging and reducing powers, and their relationships with total phenolics, flavonoid content, and antioxidant activity were investigated. A linear correlation among antioxidant activity, total phenolics, and flavonoid content was observed in concentration-dependent mode. Both extracts showed $>95 \%$ DPPH radical-scavenging activity and the higher reducing power of $3200 \mathrm{ppm}$ at the same concentration. The antioxidant potential of both extracts were compared with those of commercial antioxidants such as BHA, BHT, TBHQ, ferulic acid, and $\alpha$-tocopherol using $\mathrm{H}_{2} \mathrm{O}_{2}$ scavenging activity, inhibition of linoleic acid peroxidation, inhibition of hemolysis of rat erythrocyte induced by peroxyl radicals, and inhibition of $\mathrm{Fe}^{2+}$-induced lipid peroxidation using rat brain tissue. In the $\mathrm{H}_{2} \mathrm{O}_{2}$ scavenging activity, $\mathrm{E}$ extract showed a comparable significant antioxidant power, comparable to commercial antioxidants, and no significant difference $(\mathrm{p}>0.05)$ was found between $\mathrm{W}$ and $\mathrm{E}$ extracts on inhibition of the linoleic acid peroxidation. Whereas $\mathrm{W}$ extract exhibited a significant power in the hemolysis of rat erythrocytes, none was observed in E extract. In the Fe-induced lipid peroxidation using rat brain tissue, no significant difference $(p>0.05)$ was found between both extracts, showing a comparable activity with those of synthetic antioxidants. Both $\mathrm{W}$ and $\mathrm{E}$ extracts of dried boxthorn (Lycium chinensis) fruit may have a potential as natural antioxidants to replace synthetic antioxidants.
\end{abstract}

Keywords: Antioxidant Activity; Dried Boxthorn Fruit Extract; Phenolics; Radical Scavenging; Lipid Peroxidation

\section{Introduction}

Current interest in many traditional medicinal plants and their related health-promoting products, as a source of natural and nutritional antioxidants, is due to the increasing findings on the role of antioxidants and free radicals in human health and diseases [1,2]. Dietary intake of traditional medicinal plant-based foods is believed to reduce oxidative stress mediated by reactive oxygen species (ROS), which has been implicated as a major cause of cellular injuries in a variety of clinical abnormalities including cancer, diabetes, hepatitis, arthritis, degenerative disease, and also thought acceleration of the aging process [3]. ROS denote various forms of activated oxygen, which include free radicals such as hydroxyl radicals $(\mathrm{OH} \cdot)$, superoxide anion radicals $\left(\mathrm{O}_{2}^{-}\right)$, and non free-radical species such as hydrogen peroxide $\left(\mathrm{H}_{2} \mathrm{O}_{2}\right)$ and singlet oxygen $\left({ }^{1} \mathrm{O}_{2}\right)[4,5]$. Among the ROS, $\mathrm{H}_{2} \mathrm{O}_{2}$ is not only generated from most sources of oxidative stress and oxygen radicals but also has the ability to diffuse freely in and out of cells and tissue [6]. $\mathrm{H}_{2} \mathrm{O}_{2}$ itself is not a radical nor is it highly reactive, but instead forms highly reactive radicals such as hydroxyl radicals $(\mathrm{OH} \cdot)$ in the presence of transition metal ions by various in vivo and in vitro mechanisms [7]. Therefore, a decrease in $\mathrm{H}_{2} \mathrm{O}_{2}$ concentration could reduce hydroxyl radical formation, which results in reducing the harmful effects of oxidative damage. ROS including $\mathrm{H}_{2} \mathrm{O}_{2}$ not only play a role as endogenous oxidants in living organisms, which induce oxidative damage to biomolecules such as lipids, nucleic acids, proteins, and carbohydrates, but also cause lipid peroxidation in foods, which leads to spoiling of foods $[5,8]$.

Many antioxidant compounds naturally occurring in plant sources have been identified as free radical or active oxygen scavengers [5,9]. Plant materials contain a diverse group of phenolic compounds with antioxidant activity, which include flavonoids, lignans and stilbenes, and simple phenolic acids, such as hydroxybenzoic acids and hydroxycinnamic acids [10]. Among the phenolic compounds, the flavonoid class is known as the most prominent and 
important antioxidant, of which subclasses include flavones, isoflavones, flavanones, flavonols, flavanols, chalcones and anthocyanidins [1]. Flavonoids are reported to play roles as antioxidant by many potential pathways such as free radical scavenging, oxygen radical absorbance, and the chelating of metal ions [2,11]. Currently, interest is considerably high-lighted in finding naturally occurring antioxidants for use in foods or medicinal-based functional ingredients to replace synthetic antioxidants, which are being restricted due to their inherent side effects including carcinogenicity $[5,12,13]$. Natural antioxidants can protect the human body from free radicals and retard the progress of many chronic diseases as well as lipid oxidative rancidity in foods [14]. Therefore, the importance of study on antioxidant activity of naturally occurring medicinal plants has been paid increasingly attention.

The boxthorn (Lycium chinensis) belongs to the family Solanaceae, and its dried fruits have been traditionally regarded as a medicinal-based herb plant with bioactive properties for maintaining health [15]. For storage and consumption, the boxthorn fruits, which are harvested in summer and autumn, are first dried in the shade and then exposed to the sun for further drying until the skin is hard and dry and the pulp remaining soft with vermillion color. However, because distinction of dried boxthorn fruits from different species and varieties is difficult, substitution or adulteration in commercial products cannot be excluded. The dried boxthorn fruits called Fructus Lycii have been traditionally consumed as a health food supplement cooked as a broth with poultry and as a medicinal elixir, tea, and alcoholic liquor $[2,15]$. It is well established that $F$. Lycii contains a number of bioactive compounds having therapeutic effects on several conditions such as atherosclerosis, arterial hypertension, neurodegeneration, diabetes, aging, and night-blindness $[15,16]$. Bioactive compounds from $F$. Lycii include a cerebrocide [17], an arabinogalactan-protein [18], carotenoids lutein and xeaxanthin [19], and pro-vitamin C, 2-O-( $\beta$-d-glucopyranosyl) ascorbic acid [20]. As indicated above, several biological activities of $F$. Lycii have been reported by many investigators. In spite of the reports on the antioxidant activity of Lycium chinensis fruit $[21,22]$ to date, no information is available on the systematic comparison data for the antioxidant activity of water and ethanol extracts of Lycium chinensis fruit. The purpose of the present study was to evaluate the antioxidant activity of water and ethanol extracts obtained from Lycium chinensis fruit and to compare with those of the commercially available antioxidants. An important goal of this research was to examine the correlation between their phenolic compounds and antioxidant activity in water and ethanol extracts of the dried boxthorn (Lycium chinensis) fruits and to compare their antioxidant activities with a variety of commercial antioxidants including synthetic phenolic compounds such as butylated hydroxyl anisole (BHA), butylated hydroxyl toluene (BHT), and tert-butylhydroquinone (TBHQ). Consumers are increasingly avoiding foods prepared with preservatives of chemical origin. Natural alternatives and their related foods are therefore needed to satisfy the recent consumer's needs from all angles of stability and safety as well as biological function of foods.

\section{Materials and Methods}

\subsection{Chemicals}

1,1-Diphenyl-2-picrylhydrazyl (DPPH), linoleic acid, polyoxyethylenesorbitan monolaurate (Tween 20), ammonium thiocyanate, ferrous chloride, ferric chloride, potassium ferricyanide, aluminium chloride, sodium acetate, hydrogen peroxide $\left(\mathrm{H}_{2} \mathrm{O}_{2}\right)$, trichloroacetic acid (TCA), 2-thiobarbutric acid (TBA),

2,2'-azo-bis (2-amidino propane) dihydrochloride (AAPH), butylated hydroxyanisole (BHA), butylated hydroxyl toluene (BHT), tert-butyl hydroquinone (TBHQ), ferulic acid, $\alpha$-tocopherol, ascorbic acid, Folin-Ciocalteu reagent, gallic acid, $\mathrm{Na}_{2} \mathrm{CO}_{3}, \mathrm{NaH}_{2} \mathrm{PO}_{4}, \mathrm{Na}_{2} \mathrm{HPO}_{4}, \mathrm{NaCl}$, $\mathrm{FeSO}_{4}$ and Tris were purchased from Sigma-Aldrich Chemical Company (St. Louis, MO, USA). All other chemicals used were of analytical grade and were also obtained from Sigma-Aldrich Chemical Company (St. Louis, MO, USA).

\subsection{Extraction Procedure}

Dried boxthorn (Lycium chinensis) fruit, which was produced at Cheongyang located in the Chungchungnam-do, South Korea, was obtained from a wet market in 2009. The dried samples were stored in a freezer at $-20^{\circ} \mathrm{C}$ until analyzed. The sample $(\approx 20 \mathrm{~g})$ was refluxed twice for $1 \mathrm{~h}$ each time with $200 \mathrm{ml}$ of distilled water according to a method described by Tang, et al. [23]. The water solution was cooled, filtered, and concentrated under reduced pressure, and then lyophilized to obtain a water extract. The yield of dried residue corresponded to $47.216 \%$ (9.361 \pm $0.218 \mathrm{~g}, \mathrm{n}=3$ ) of the original dry fruit weight. A part of the water extract obtained from the dried boxthorn fruit was diluted and prepared with distilled water at different concentrations used for measurement of antioxidant activity. The ethanol $(95 \%, \mathrm{v} / \mathrm{v})$ extract of the dried boxthorn fruit (ethanol extract yield 38.637\%: $7.736 \pm 0.223$ $\mathrm{g}, \mathrm{n}=3$ ) was also obtained and prepared by the same method used in the water extract.

\subsection{DPPH Free Radical Scavenging Activity}

The free radical-scavenging activity of dried boxthorn fruit extracts (water extract, W extract: ethanol extract, E ex- 
tract) at different concentrations [5 to $4000 \mathrm{ppm}(\mu \mathrm{g} / \mathrm{ml})$ ] was measured by the 1,1-diphenyl-2-picryl hydrazyl (DPPH) method outlined by Kim [24] based on the method of Hatano, et al. [25]. $\mathrm{W}$ and $\mathrm{E}$ extracts $(4 \mathrm{ml}$ each) were dissolved in water and ethanol mixture (Etoh: $\left.\mathrm{H}_{2} \mathrm{O}=6: 4\right)$ and added to a solution of DPPH $(1 \mathrm{ml}, 0.2 \mathrm{mM})$ radical in methanol. The mixture was reacted for $30 \mathrm{~min}$ prior to the analysis, and the absorbance of reaction mixture $(0.1$ $\mathrm{ml}$ ) was measured at $517 \mathrm{~nm}$. The scavenging activity of extracts was determined by Equation (1):

DPPH free radical - scavenging activity (\%)

$$
=\left[\left(\mathrm{A}_{\mathrm{c}}-\mathrm{A}_{\mathrm{t}} / \mathrm{A}_{\mathrm{c}}\right) \times 100\right]
$$

where $A_{c}$ is the absorbance of control reaction (blank sample treated with no added extract) and $\mathrm{A}_{t}$ is the absorbance in the presence of extract.

\subsection{Total Phenolic Content}

The concentration of total phenolic compounds of $\mathrm{W}$ and E extracts were determined spectrophotometrically using Folin-Ciocalteu reagent [26] according to a method of Lim, et al. [27]. Each extract $(0.1 \mathrm{ml})$ at different concentrations $[50,200,800,1600$, and $3200 \mathrm{ppm}(\mu \mathrm{g} / \mathrm{ml})]$ was diluted with distilled water $(7.9 \mathrm{ml})$ and added with Folin-Ciocalteu phenol reagent $(0.5 \mathrm{ml})$. After $1 \mathrm{~min}, 1.5$ $\mathrm{ml}$ of $20 \%$ sodium carbonate solution was added and mixed thoroughly. The mixture was allowed to stand for 1 $\mathrm{h}$, and the absorbance was measured at $750 \mathrm{~nm}$. Phenolic content was expressed in micrograms per milliliter of extract at different concentrations based on a standard curve of gallic acid, which was expressed as milligrams per liter of gallic acid equivalent (GAE).

\subsection{Flavonoid Content}

Flavonoid contents of $\mathrm{W}$ and $\mathrm{E}$ extracts were determined using the methods described by Atmani, et al. [28] and Marksimović, et al. [29]. Aliquots (10 ml) of extract solution prepared at different concentrations [50, 200, 800, 1600 , and $3200 \mathrm{ppm}(\mu \mathrm{g} / \mathrm{ml})$ ] were mixed with $2 \mathrm{ml}$ water and $5 \mathrm{ml}$ of $\mathrm{AlCl}_{3}$ reagent $(133 \mathrm{mg}$ crystalline aluminum chloride and $400 \mathrm{mg}$ crystalline sodium acetate were dissolved in $100 \mathrm{ml}$ of water), and the absorbance was measured at $430 \mathrm{~nm}$. The concentrations of flavonoids were deduced from a standard curve and calculated in $\mu \mathrm{g}$ quercetine equivalent per $\mathrm{ml}$ sample extract.

\subsection{Reducing Power}

The reducing power of $\mathrm{W}$ and $\mathrm{E}$ extracts were determined using the method of Kim [24] based on the method described by Oyaizu [30]. To $0.1 \mathrm{ml}$ of extract solution at different concentrations $[0,50,200,800,1600$, and 3200 ppm $(\mu \mathrm{g} / \mathrm{ml})]$, phosphate buffer $(0.25 \mathrm{ml}, 0.2 \mathrm{M}, \mathrm{pH} 6.6)$ and potassium ferricyanide $\left[\mathrm{K}_{3} \mathrm{Fe}(\mathrm{CN})_{6}\right](0.25 \mathrm{ml}, 1 \%)$ were mixed and incubated at $50^{\circ} \mathrm{C}$ for $20 \mathrm{~min}$. Aliquots $(0.25 \mathrm{ml})$ of trichloroacetic acid $(10 \%)$ were added to the mixture and centrifuged for $10 \mathrm{~min}$ at $1700 \mathrm{~g}\left(25^{\circ} \mathrm{C}\right)$. The upper layer of solution $(0.25 \mathrm{ml})$ was mixed with distilled water $(0.25 \mathrm{ml})$ and ferric chloride $\left[\mathrm{FeCl}_{3}\right](0.05 \mathrm{ml}$, $0.1 \%$ ) and the absorbance was measured at $700 \mathrm{~nm}$.

\subsection{Activity Comparison of the Dried Boxthorn Fruit Extracts with Commercial Antioxidants}

\subsection{1. $\mathrm{H}_{2} \mathrm{O}_{2}$ Scavenging Activity}

The hydrogen peroxide scavenging capacities of $\mathrm{W}$ and $\mathrm{E}$ extracts at $3200 \mathrm{ppm}(\mu \mathrm{g} / \mathrm{ml})$ were determined and compared with those of commercial antioxidants (BHA, BHT, TBHQ, ferulic acid, and $\alpha$-tocopherol) by the method of Atmani, et al. [28] with slight modifications. The concentration of commercial antioxidants used for comparison was $87.00 \mathrm{ppm}(\mu \mathrm{g} / \mathrm{ml})$ because both $\mathrm{W}$ and E extracts at $3200 \mathrm{ppm}$ contained $87.00 \mu \mathrm{g}$ of total phenolics. The concentration of test tubes was prepared with $2 \mathrm{ml}$ of test sample and $\mathrm{H}_{2} \mathrm{O}_{2}(1.2 \mathrm{ml}, 20 \mathrm{mM})$ in phosphate buffer ( $\mathrm{pH}$ 7.4). A blank solution was prepared by the same way but without $\mathrm{H}_{2} \mathrm{O}_{2}$. After incubation of the mixture during $10 \mathrm{~min}$, the absorbance was recorded at 230 $\mathrm{nm}$. The $\mathrm{H}_{2} \mathrm{O}_{2}$ scavenging activity was evaluated using Equation (2):

$$
\mathrm{H}_{2} \mathrm{O}_{2} \text { scavenging activity }(\%)=\left[\left(\mathrm{A}_{\mathrm{c}}-\mathrm{A}_{\mathrm{t}}\right) / \mathrm{A}_{\mathrm{c}} \times 100\right]
$$

where $A_{c}$ is the absorbance of the control and $A_{t}$ is the absorbance of the test sample.

\subsubsection{Inhibition Activity of Linoleic Acid Peroxidation Using Ferric Thiocyanate Method (FTC)}

The antioxidant activities of $\mathrm{W}$ and $\mathrm{E}$ extracts $[3200 \mathrm{ppm}$ $(\mu \mathrm{g} / \mathrm{ml})]$ on linoleic acid peroxidation in an emulsion were determined and compared with those of the commercial antioxidants (BHA, BHT, TBHQ, ferulic acid, and $\alpha$-tocopherol) by a method outlined by Kim [24] based on the thiocyanate method of Yen, et al. [31]. A sample solution $(0.5 \mathrm{ml})$ was mixed with $2.5 \mathrm{ml}$ of linoleic acid $(0.02 \mathrm{M})$ emulsion at $\mathrm{pH} 7.0$ and $2 \mathrm{ml}$ of phosphate buffer $(0.2 \mathrm{M})$ at $\mathrm{pH}$ 7.0. The linoleic acid emulsion was prepared by mixing $0.2804 \mathrm{~g}$ of linoleic acid, $0.2804 \mathrm{~g}$ of Tween 20 as emulsifier and $50 \mathrm{ml}$ of phosphate buffer. The reaction mixture was incubated at $37^{\circ} \mathrm{C}$ for $6 \mathrm{~d}$. At $24 \mathrm{~h}$-intervals, the reaction mixture $(0.1 \mathrm{ml})$ was transferred to a test tube and subsequently supplemented with $75 \% \mathrm{EtOH}(4.7 \mathrm{ml})$, $30 \%$ ammonium thiocyanate $(0.1 \mathrm{ml})$, and $0.02 \mathrm{M}$ ferrous chloride in $3.5 \% \mathrm{HCl}(0.1 \mathrm{ml})$. The absorbance was recorded at $500 \mathrm{~nm}$. The percent inhibition of linoleic acid 
peroxidation in an emulsion was calculated by Equation (3):

$$
\% \text { inhibition of peroxidation }=100-\left[\left(A_{t} / A_{c}\right) \times 100\right]
$$

where $A_{c}$ is the absorbance of control (without sample), and $A_{t}$ is the absorbance of the experimental (with sample) reaction.

\subsubsection{Inhibition Activity of Erythrocyte Hemolysis Mediated by Peroxyl Free Radicals}

The antioxidant activities of $\mathrm{W}$ and E extracts $[3200 \mathrm{ppm}$ $(\mu \mathrm{g} / \mathrm{ml})]$ on the inhibition of erythrocyte hemolysis was determined and compared with those of commercial antioxidants (BHA, BHT, TBHQ, ferulic acid, and $\alpha$-tocopherol) according to the procedures described by Cheung, et al. [32]. Blood was obtained from Male Sprague-Dawley rats $(200 \mathrm{~g})$. Erythrocytes separated from the plasma followed by three times washing of buffy coat with $10 \mathrm{ml}$ of $10 \mathrm{mM}$ phosphate-buffered saline (PBS) at $\mathrm{pH} 7.4$ and centrifuged at $1000 \mathrm{~g}$ for $5 \mathrm{~min}$. After the $3 \mathrm{rd}$ wash, the erythrocytes were obtained by centrifugation at $1000 \mathrm{~g}$ for 10 min and resuspended in PBS to obtain a $20 \%$ suspension of erythrocytes. Hemolysis of erythrocytes mediated by 2 , 2'-azo-bis (2-amidinopropane) dihydrochloride (AAPH; a peroxyl radical initiator) was measured according to the method of Miki, et al. [33]. A portion of erythrocyte suspension $(0.1 \mathrm{ml})$ was mixed with $0.1 \mathrm{ml}$ of PBS solution containing either extract or commercial antioxidant, and an aliquot of $200 \mathrm{mM}$ AAPH $(0.2 \mathrm{ml}$, in PBS) was then added to the mixture. The reaction mixture was shaken gently while being incubated in a water bath at $37^{\circ} \mathrm{C}$ for $3 \mathrm{~h}$. The reaction mixture was diluted with $8 \mathrm{ml}$ PBS and centrifuged at $1000 \mathrm{~g}$ for $10 \mathrm{~min}$. The absorbance of its supernatant was then read at $540 \mathrm{~nm}\left(\mathrm{~A}_{\mathrm{abs}}\right)$. Similarly described above for the determination of $\mathrm{A}_{\mathrm{abs}}$, the reaction mixture was treated with $8 \mathrm{ml}$ of distilled water to achieve a complete hemolysis, and the absorbance of the supernatant obtained after centrifugation was measured at $540 \mathrm{~nm}\left(\mathrm{~B}_{\mathrm{abs}}\right)$. The percentage hemolysis inhibition was calculated by Equation (4):

$\%$ hemolysis inhibition $=\left(1-\mathrm{A}_{\mathrm{abs}} / \mathrm{A}_{\mathrm{abs}}\right) \times 100$

\subsubsection{Inhibition Activity of Lipid Peroxidation Using Rat Brain Tissue}

The antioxidant activities of $\mathrm{W}$ and E extracts $[3200 \mathrm{ppm}$ $(\mu \mathrm{g} / \mathrm{ml})]$ on lipid peroxidation of the rat brain tissue stimulated by $\mathrm{Fe}^{2+} /$ ascobate were assayed and compared with those of commercial antioxidants (BHA, BHT, TBHQ, ferulic acid, and $\alpha$-tocopherol) according to the method of Lim, et al. [27]. Brains of Sprague-Dawley rats were dissected and homogenized with a Polytron (Brinkmann Instruments, Westbury, NY) in ice-cold $20 \mathrm{mM}$ Tris- $\mathrm{HCl}$ buffer ( $\mathrm{pH} 7.4)$ to produce a 1:2 (w/v) brain tissue ho- mogenate, which was then centrifuged at $3000 \mathrm{~g}$ for 10 min. The supernatant was used for the study of lipid peroxidation as determined using the formation of malondialdehyde (MDA) as an indicator. Aliquot $(0.1 \mathrm{ml})$ of the supernatant was incubated with $0.2 \mathrm{ml}$ of sample (dried boxthorn fruit extracts or commercial antioxidants) in the presence of $0.1 \mathrm{ml}$ of $10 \mu \mathrm{M} \mathrm{FeSO}_{4}$ and $0.1 \mathrm{ml}$ of $0.1 \mathrm{mM}$ ascorbic acid at $37^{\circ} \mathrm{C}$ for $1 \mathrm{~h}$. The reaction was stopped by adding trichloroacetic acid (TCA) and thiobarbituric acid (TBA), and the mixture was then heated at $80^{\circ} \mathrm{C}$ for $20 \mathrm{~min}$. After centrifugation at $3000 \mathrm{~g}$ for $10 \mathrm{~min}$ to remove the precipitated protein, the color intensity of the MDA-TBA complex in the supernatant was measured at $532 \mathrm{~nm}$ using a spectrophotometer. The percent lipid peroxidation was calculated according to Equation (5):

$$
\% \text { lipid peroxidation inhibition }=\left(1-\mathrm{A}_{1} / \mathrm{A}_{0}\right) \times 100(5)
$$

where $A_{0}$ is the absorbance of control, and $A_{1}$ is the absorbance of the test sample.

\subsection{Statistical Analysis}

All determinations for antioxidant activity in the samples were carried out in triplicate $(n=3)$, and all values were reported as mean \pm standard deviation. All experimental data were analyzed with the analysis of variance (ANOVA) using General Linear Model, and significant differences $(p<0.05)$ among means at each treatment were determined using the Tukey's multiple range test at a level of $\alpha=0.05$ using Minitab computing system (Minitab Inc., State College, PA).

\section{Results and Discussion}

Free radicals are involved in the normal physiology of living organisms. The excess of free radicals and reactive oxygen species have been proposed to induce cellular oxidative damage, which results in a variety of chronic diseases such as cancer, arteriosclerosis, inflammatory disorders as well as aging process [34,35]. Recently consumers' interest has been focused on several traditional medicinal herbs and their related formulation food products which have free radical-scavenging potential. The traditional medicinal-based plants or herbs provide us with many kinds of antioxidants as well as health-promoting nutraceuticals, which scavenge free radicals and reactive oxygen species, resulting in treatment of various chronic diseases and protection against oxidative rancidity of foods $[24,36]$.

\subsection{Antioxidant Activity of the Dried Boxthorn Fruit Extracts}

\subsubsection{DPPH Free Radical Scavenging Activity}

$\mathrm{DPPH}$ is a free radical compound that has been widely 
used to determine the free radical-scavenging ability of various samples and decreases significantly depending on the exposure to proton radical scavengers [37]. The reduction capability of DPPH. radicals are determined by the decrease in the absorbance at $517 \mathrm{~nm}$, which is induced by antioxidants [24]. The DPPH free radical scavenging activities of the dried boxthorn fruit extracts (W and $\mathrm{E}$ extracts) at different concentrations are presented in Figure 1. For each extract, different concentrations [5 to 4000 ppm $(\mu \mathrm{g} / \mathrm{ml})]$ were prepared, and the activities of both extracts showed a similar trend in a concentration-dependant mode. The increasing scavenging activity upon increasing concentration of extracts is due to the decrease in the concentration of DPPH radical, which indicates the reduction capability of DPPH radicals by the antioxidants present in extracts. As shown in the Table 1, the scavenging activity of $\mathrm{W}$ extracts was significantly higher $(p<0.05)$ depending on the increasing concentration from 50 to $3200 \mathrm{ppm}$, whereas the activity of E extracts was not significantly different $(p>0.05)$ between concentrations of 1600 and $3200 \mathrm{ppm}$. However, at $3200 \mathrm{ppm}$, both $\mathrm{W}$ and $\mathrm{E}$ extracts reached the maximum scavenging ability against DPPH radicals of $97.368 \%$ and $96.924 \%$, respectively (Table 1). These results indicates that both $\mathrm{W}$ and $\mathrm{E}$ extracts have noticeable effects on the scavenging of free radical in a concentration-dependant mode with higher scavenging activity upon increasing concentration of extracts.

\subsubsection{Relationship between Radical Scavenging Andtotal Phenolic and Flavonoid Content}

In an attempt to establish a potential relationship with antioxidant activity established by DPPH free radical- scavenging activity, the total phenolics and flavonoid content at different concentrations of $\mathrm{W}$ and $\mathrm{E}$ extracts were determined and are summarized in Table 1. The concentration at which both dried boxthorn fruit extracts show the maximum scavenging activity against DPPH radicals was $3200 \mathrm{ppm}, 86.718 \mu \mathrm{g} / \mathrm{ml}$ for total phenolics and 5.274 $\mu \mathrm{g} / \mathrm{ml}$ for flavonoids in W extract, whereas $86.013 \mu \mathrm{g} / \mathrm{ml}$ for total phenolics and $8.103 \mu \mathrm{g} / \mathrm{ml}$ for flavonoids in E extract. The correlations among total phenolics and flavonoid content, and DPPH free radical scavenging activity of both $\mathrm{W}$ and $\mathrm{E}$ extracts are shown in Figures 2 and 3. Total phenolic content in both $\mathrm{W}$ and $\mathrm{E}$ extracts increased in a concentration-dependant mode in the range of 50 to $3200 \mathrm{ppm}$ and were significantly higher $(\mathrm{p}<$ 0.05 ) upon the increase of concentration in both extracts (Table 1). The scavenging activity against DPPH radicals at different concentrations also significantly $(\mathrm{p}<0.05)$

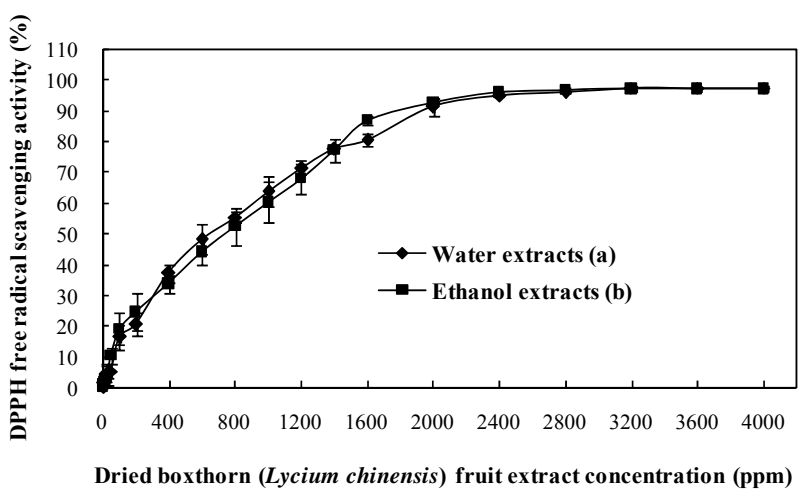

Figure 1. Free radical-scavenging activities of water and ethanol extracts of the dried boxthorn fruit (Lycium chinensis) at different concentrations against 1,1-diphenyl-2picrylhydrazyl (DPPH) radicals.

Table 1. Free radical scavenging activity, reducing power, and total phenolic and flavonoid contents in water (a) and ethanol (b) extracts of dried boxthorn fruit (Lycium chinensis) at different concentrations.

\begin{tabular}{cccccc}
\hline \multirow{2}{*}{ Extract } & $\begin{array}{c}\text { Concentration } \\
(\mathrm{ppm})\end{array}$ & \multicolumn{4}{c}{ Dried boxthorn fruit (Lycium chinensis) extracts } \\
\cline { 3 - 6 } & 50 & $1.686 \pm 0.344 \mathrm{a}$ & $0.004 \pm 0.005 \mathrm{a}$ & $5.111 \pm 0.190 \mathrm{a}$ & $0.144 \pm 0.004 \mathrm{a}$ \\
& 200 & $4.453 \pm 0.493 \mathrm{~b}$ & $0.291 \pm 0.084 \mathrm{a}$ & $20.503 \pm 3.788 \mathrm{~b}$ & $0.316 \pm 0.017 \mathrm{~b}$ \\
Water extract & 800 & $19.784 \pm 0.799 \mathrm{c}$ & $1.205 \pm 0.066 \mathrm{~b}$ & $55.256 \pm 1.651 \mathrm{c}$ & $0.911 \pm 0.018 \mathrm{c}$ \\
(a) & 1600 & $45.614 \pm 0.977 \mathrm{~d}$ & $1.965 \pm 0.243 \mathrm{c}$ & $80.503 \pm 1.889 \mathrm{~d}$ & $0.976 \pm 0.018 \mathrm{~d}$ \\
& 3200 & $86.718 \pm 0.677 \mathrm{e}$ & $5.274 \pm 0.118 \mathrm{~d}$ & $97.368 \pm 0.452 \mathrm{e}$ & $1.369 \pm 0.017 \mathrm{e}$ \\
\hline & 50 & $0.916 \pm 0.094 \mathrm{a}$ & $0.254 \pm 0.125 \mathrm{a}$ & $10.102 \pm 2.800 \mathrm{a}$ & $0.167 \pm 0.002 \mathrm{a}$ \\
Ethanol extract & 200 & $9.192 \pm 0.908 \mathrm{~b}$ & $0.603 \pm 0.252 \mathrm{a}$ & $24.386 \pm 5.940 \mathrm{~b}$ & $0.320 \pm 0.006 \mathrm{~b}$ \\
(b) & 800 & $15.224 \pm 1.122 \mathrm{c}$ & $2.011 \pm 0.057 \mathrm{~b}$ & $52.376 \pm 5.980 \mathrm{c}$ & $0.983 \pm 0.025 \mathrm{c}$ \\
& 1600 & $35.012 \pm 1.102 \mathrm{~d}$ & $4.685 \pm 0.254 \mathrm{c}$ & $86.806 \pm 1.470 \mathrm{~d}$ & $1.315 \pm 0.024 \mathrm{~d}$ \\
& 3200 & $86.013 \pm 1.063 \mathrm{e}$ & $8.103 \pm 0.130 \mathrm{~d}$ & $96.924 \pm 0.580 \mathrm{~d}$ & $1.466 \pm 0.012 \mathrm{e}$ \\
\hline
\end{tabular}

${ }^{1} \mu \mathrm{g}$ gallic acid equivalent/ml of extract at different concentration; ${ }^{2} \mu \mathrm{g}$ quercetin equivalent $/ \mathrm{ml}$ of extract at different concentration; ${ }^{3} \mathrm{DPPH}$ radical-scavenging activity $(\%)=[($ absorbance of control at $517 \mathrm{~nm}-$ absorbance of sample at $517 \mathrm{~nm}) /($ absorbance of control at $517 \mathrm{~nm})] \times 100 ;{ }^{4} \mathrm{Absorbance}$ at $700 \mathrm{~nm}$; Values with different letters in each column are significantly different $(\mathrm{p}<0.05)$; Each value is the mean \pm standard deviation; $\mathrm{n}=3$. 


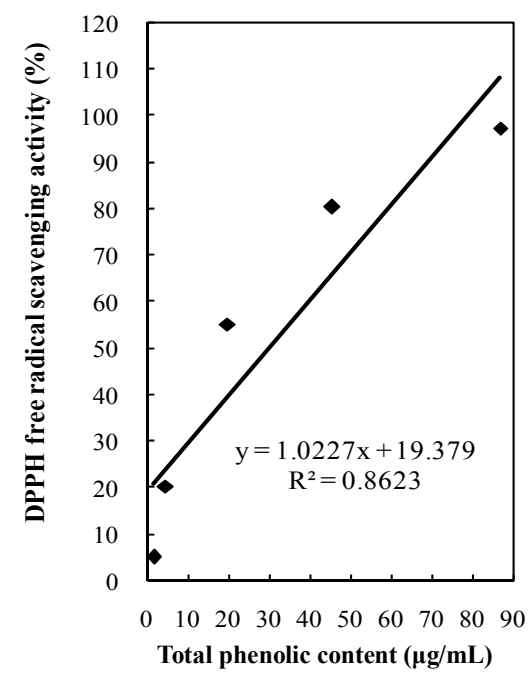

(a)

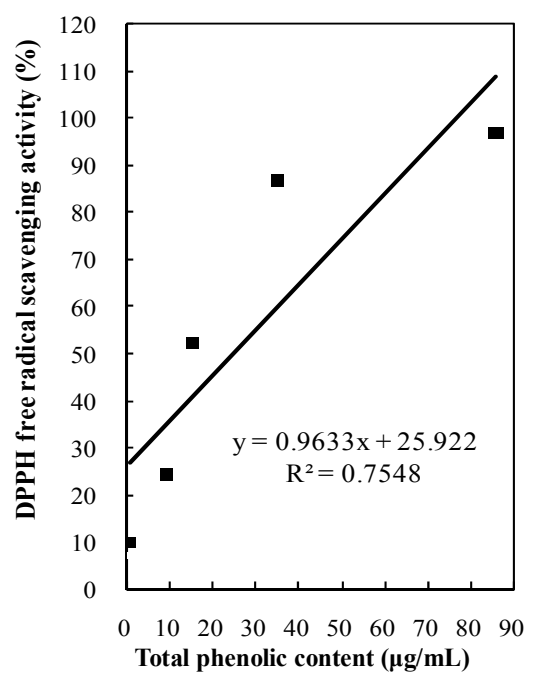

(b)

Figure 2. Correlation between the free radical-scavenging activity and total phenolic contents of water and ethanol extracts of the dried boxthorn fruit (Lycium chinensis) at different concentrations. (a) Water extracts; (b) Ethanol extracts.

increased according to the increasing concentration of total phenolic content (Table 1).

As a result, a linear correlation between the total phenolic content and the DPPH radical scavenging activity in the both extracts was found in Figure 2. The correlation coefficients between the antioxidant activity monitored by DPPH method and the total phenolic contents of both $\mathrm{W}$ and $\mathrm{E}$ extracts were determined and observed as $\mathrm{R}^{2}=0.8623$ for $\mathrm{W}$ extract and $\mathrm{R}^{2}=0.7548$ for $\mathrm{E}$ extract (Figures 2(a) and (b)). In addition, the flavonoid content, in agreement with the results of the total phenolic content of both $\mathrm{W}$ and $\mathrm{E}$ extracts, was also increased in a concentration-dependant mode within the range of 50 to $3200 \mathrm{ppm}$ and significantly differed $(\mathrm{p}<0.05)$ at different concentrations of both extracts (Table 1). The DPPH free-radical scavenging activity at different concentrations of the extracts were also significantly different $(p<0.05)$ depending on the increasing concentration of both $\mathrm{W}$ and E extracts, which indicated a linear correlation between the flavonoid content and the antioxidant activity with correlation coefficients of $\mathrm{R}^{2}=0.7831$ for $\mathrm{W}$ extract and $\mathrm{R}^{2}=0.8861$ for E extract (Figures 3(a) and (b)). Therefore, these results are in good accordance with those of previous studies, which indicated that high total phenolic content increased the antioxidant activity [38,39]. Although a good correlation was observed between the radical scavenging activity and total phenolic and flavonoid contents, the DPPH radical scavenging activity in W extract showed relatively higher correlation with the total phenolic content $\left(\mathrm{R}^{2}=0.8623\right)$ than the flavonoid content $\left(\mathrm{R}^{2}=0.7831\right)$, whereas the DPPH radical scavenging activity in E extract showed the opposite trend. These results indicate the antioxidant activity of dried boxthorn fruit extracts based on DPPH scavenging activity could be attributed to the presence of phenolic compounds as major components in both extracts. Plant phenolics constitute one of the major groups of compounds acting as primary antioxidants or free radical terminators $[40,41]$. Phenolic compounds such as flavonoids, phenolic acids, and tannins are considered to be the major contributors to the antioxidant activity of fruits and medicinal plants [41].

\subsubsection{Relationship between Reducing Power and Total Phenolic and Flavonoid Content}

The reducing power of both $\mathrm{W}$ and $\mathrm{E}$ extracts at different concentrations, which was investigated by the $\mathrm{Fe}^{3+}-\mathrm{Fe}^{2+}$ transformation in the presence of dried boxthorn fruit extracts, are presented in Table $1[24,30]$. The reducing capacity of a compound may serve as a significant indicator of its potential antioxidant activity [42] which can be measured by the ability of a compound to donate electron in an oxidation-reduction reaction [2]. As shown in data of the antioxidant activity monitored by DPPH radical scavenging method, the reducing powers in both $\mathrm{W}$ and $\mathrm{E}$ extracts also significantly increased $(\mathrm{p}<0.05)$ with increasing concentration of extracts (Table 1). It can be easily deduced that both $\mathrm{W}$ and $\mathrm{E}$ extracts obtained from the dried fruits of Lycium chinensis Miller has a strong electron-donating capability and hence reducing capacity. The highest reducing powers of both extracts were obtained from the same concentration of $3200 \mathrm{ppm}$ (Table 1). Just as the relationship with antioxidant activity suggested by DPPH free-radical scavenging power, another potential relationship with antioxidant activity established by reducing power, total phenolics, and flavonoid content at different concentrations of extracts was deter- 


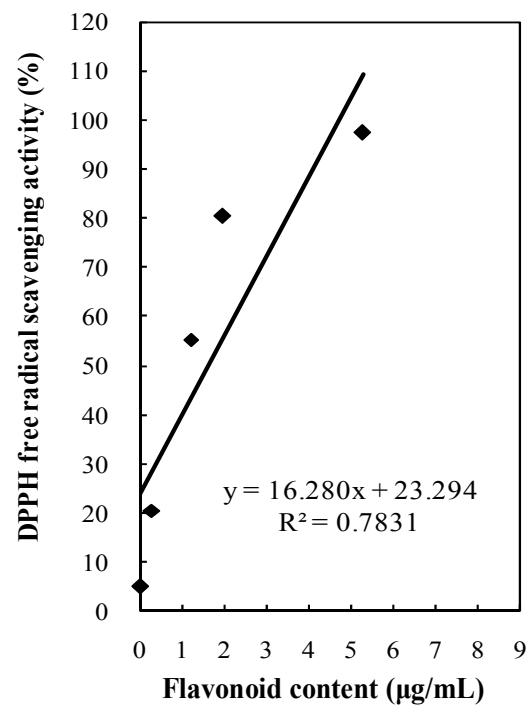

(a)

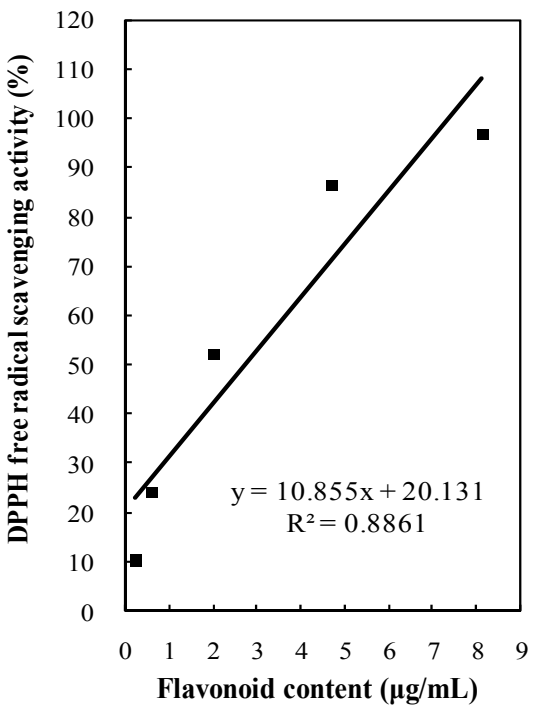

(b)

Figure 3. Correlation between the free radical-scavenging activity and flavonoid content of water and ethanol extracts of the dried boxthorn fruit (Lycium chinensis) at different concentrations. (a) Water extracts; (b) Ethanol extracts.

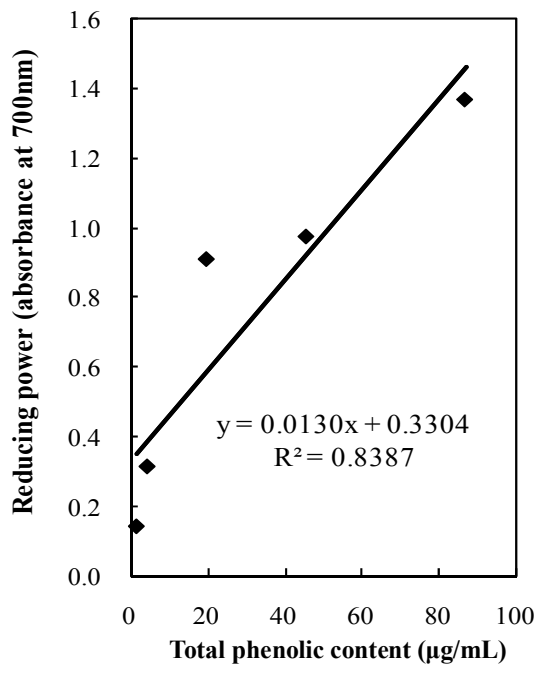

(a)

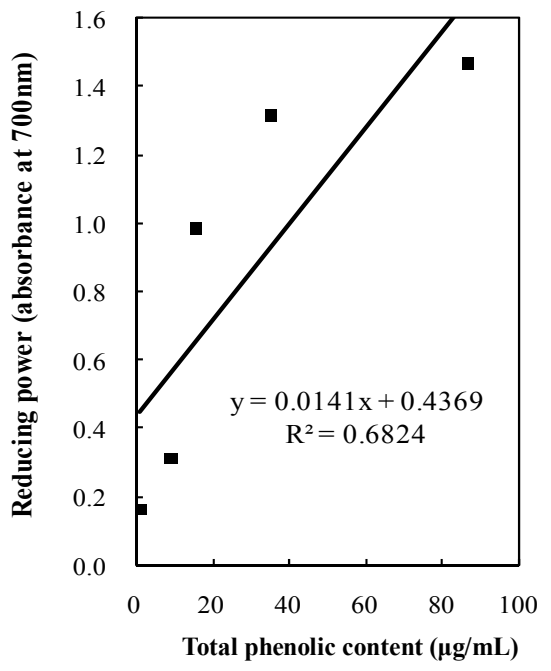

(b)

Figure 4. Correlation between the reducing power and total phenolic content of water and ethanol extracts of the dried boxthorn fruit (Lycium chinensis) at different concentrations. (a) Water extracts; (b) Ethanol extracts.

mined and plotted in the Figures $\mathbf{4}$ and $\mathbf{5}$. The reducing powers of both extracts at different concentrations linearly increased with increasing concentration of total phenolic content (Figures 4(a) and (b)). However, results of the present study indicated the presence of a relatively strong correlation between the reducing power and total phenolic content of $\mathrm{W}$ extract with correlation coefficient of $\mathrm{R}^{2}=0.8387$, whereas, a relatively weak correlation was found between the reducing power and total phenolic content of $E$ extract with correlation coefficient of $R^{2}=0.6824$.

In addition, the flavonoid content, in agreement with the result of the total phenolic contents of both $\mathrm{W}$ and $\mathrm{E}$ extracts, linearly increased in a concentration-dependant mode within the range of 50 to $3200 \mathrm{ppm}$ (Figures 5(a) and (b)), which indicated a strong correlation between the flavonoid content and the antioxidant activity monitored by reducing power with correlation coefficients of $\mathrm{R}^{2}=$ 0.8066 for $\mathrm{W}$ extract and $\mathrm{R}^{2}=0.8223$ for $\mathrm{E}$ extract (Figures 5(a) and (b)). These results show the antioxidant activity of dried boxthorn fruit extracts based on reducing capacity is due to the presence of phenolic compounds including flavonoids in both extracts. The antioxidant activ- 


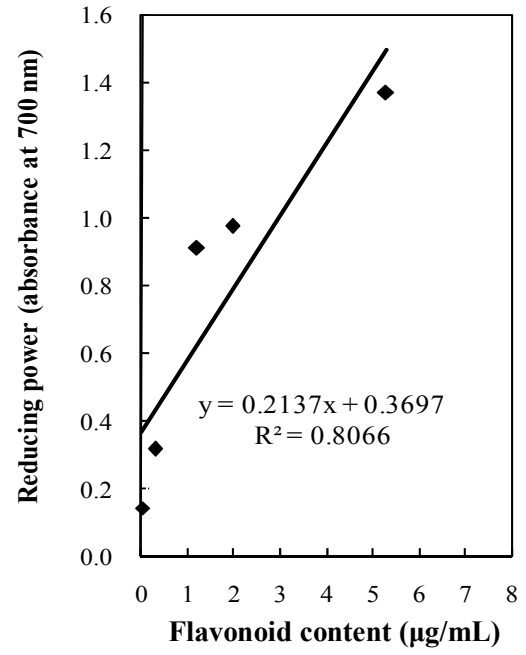

(a)

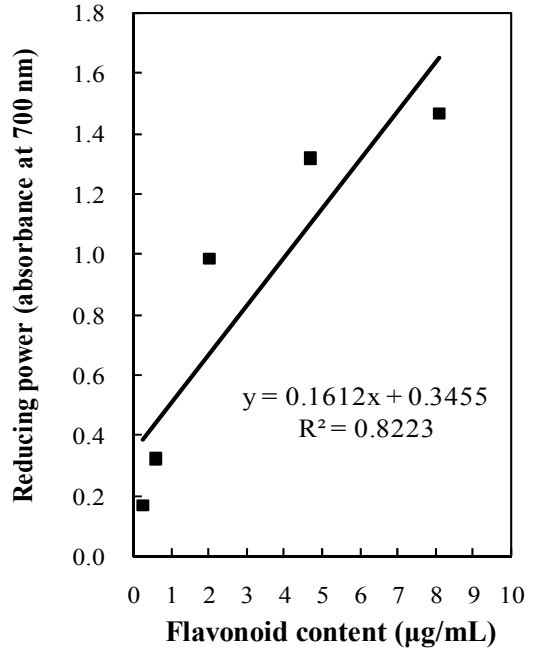

(b)

Figure 5. Correlation between the reducing power and flavonoid content of water and ethanol extracts of dried boxthorn fruit (Lycium chinensis) at different concentrations. (a) Water extracts; (b) Ethanol extracts.

ity of the phenolic compounds was attributed to its redox properties, which allow them to act as reducing agents, hydrogen or electron donators, singlet oxygen quenchers as well as metal chelating agents [43].

\subsection{Comparison of the Antioxidant Activity with Commercial Antioxidants}

Based on the results of the antioxidant activity, which was monitored by DPPH radical-scavenging activity and reducing power, of dried boxthorn fruit extracts at different concentrations, the optimum concentration with the maximum activity was selected and compared to the antioxidant activity of commercial phenolic compounds widely used in food industry. The concentration of extracts used for comparison measurements was $3200 \mathrm{ppm}$ with the best activity for both $\mathrm{W}$ and $\mathrm{E}$ extracts. The activities of commercial antioxidants such as BHA, BHT, TBHQ, ferulic acid, and $\alpha$-tocopherol, which are well-known as phenolic compounds, were determined at the concentration of $86.365 \mu \mathrm{g} / \mathrm{ml}$ and compared with that of dried boxthorn extracts. Parameters tested for comparison included four assays, $\mathrm{H}_{2} \mathrm{O}_{2}$ scavenging, inhibition of linoleic acid peroxidation using emulsion system, inhibition of erythrocyte hemolysis, and inhibition of lipid peroxidation using rat brain tissue.

\subsection{1. $\mathrm{H}_{2} \mathrm{O}_{2}$ Scavenging Activity}

The ability of both $\mathrm{W}$ and E extracts to scavenge hydrogen peroxide was determined and compared with those of BHA, BHT, TBHQ, ferulic acid, and $\alpha$-tocopherol. E extract, at a concentration of $3200 \mathrm{ppm}$, showed a significantly high scavenging capacity $(\mathrm{p}<0.05)$ against $\mathrm{H}_{2} \mathrm{O}_{2}$, which is comparable to the commercial phenolic antioxi- dant, ferulic acid, whereas W extract showed a poor capacity of $20.085 \%$ (Figure 6). Compared with other comercial antioxidants, the order of the antioxidant activity by $\mathrm{H}_{2} \mathrm{O}_{2}$ scavenging was as follows: ferulic acid (83.703\%) $\geq \mathrm{E}$ extract $(83.394 \%)>\mathrm{BHA}(28.632 \%)>\mathrm{W}$ extract $(20.085 \%)>\operatorname{BHT}(6.288 \%) \geq$ TBHQ $(3.972 \%) \geq \alpha$-Toco $(3.735 \%)$ (Figure 6). The relatively higher scavenging activity of $\mathrm{E}$ extract against $\mathrm{H}_{2} \mathrm{O}_{2}$ strongly suggests that $\mathrm{E}$ extract obtained from the dried boxthorn fruit contains the necessary compounds for $\mathrm{H}_{2} \mathrm{O}_{2}$ elimination at high level, whereas lower in the $\mathrm{W}$ extract. In a study carried out on a medicinal plant (Pistacia terebinthus) leaf, results showed that the methanol leaf extract, at $50 \mu \mathrm{g} / \mathrm{ml}$, had the same scavenging activity $(67 \%)$ on $\mathrm{H}_{2} \mathrm{O}_{2}$ as that of ascorbic acid at $12.5 \mu \mathrm{g} / \mathrm{ml}$ and higher than that of BHT $(50 \%)$ at the same concentration [44]. It is well established that $\mathrm{H}_{2} \mathrm{O}_{2}$ itself is not very reactive, but can occasionally be toxic to cells due to its ability to form hydroxyl radicals, thereby emphasizing the importance of eliminating $\mathrm{H}_{2} \mathrm{O}_{2}$ [45].

\subsubsection{Inhibition Activity on Linoleic Acid Peroxidation}

The results of linoleic acid peroxidation, as determined by the ferric thiocyanate (FTC) method, at $37^{\circ} \mathrm{C}$ after addition of $\mathrm{W}$ extract, E extract, BHT, BHA, TBHQ, ferulic acid, and $\alpha$-tocopherol are plotted in Figutr 7, and the inhibition percentage of peroxide formed during incubation in linoleic acid emulsion are shown in Table 2. The absorbance values by FTC method (Figure 7), which is used to measure the amount of peroxide at the primary stage of linoleic acid peroxidation, indicated that the higher the absorbance values, the lower the level of antioxidant 
activity $[24,46]$. In general, both $\mathrm{W}$ and $\mathrm{E}$ extracts markedly inhibited the oxidation of linoleic acid for 6 days when compared to control. In the early stages, the oxidation of linoleic acid without added extracts (control) was accompanied by a rapid increase of peroxide value on day 5 days of experiment. The control showed a significant increase $(p<0.05)$ in the absorbance values during incubation and reached the maximum level on day 5 , and finally dropped on day 6 . This reduction is due to the accumulation of malonaldehyde compounds, which are a decomposed product of peroxide, resulting from linoleic acid oxidation [24]. Significant differences $(p<0.05)$ were found between the control and the linoleic acid-containing boxthorn fruit extracts, which slowed the higher rate of peroxide formation than those of the commercial antioxidants such as BHT, BHA, TBHQ, ferulic acid, and $\alpha$-tocopherol. The results of the present study showed $\mathrm{W}$ extract exhibited the highest antioxidant activity compared to those of other antioxidant compounds, but no significant difference $(\mathrm{p}>0.05)$ was found between $\mathrm{W}$ and $\mathrm{E}$ extracts (Table 2). The high antioxidant activity of the

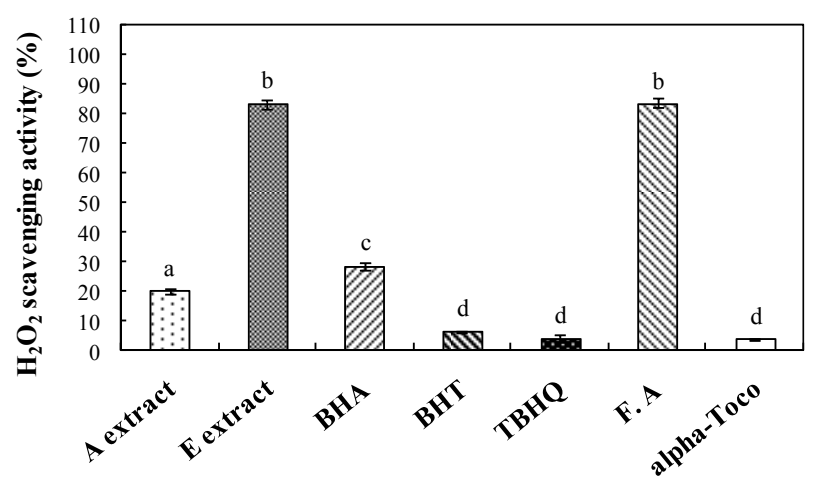

Figure 6. Comparison of $\mathrm{H}_{2} \mathrm{O}_{2}$ scavenging activities between the dried boxthorn fruit (Lycium chinensis) extracts and commercial antioxidants. Bars with different letters are significantly different $(p<0.05) ; n=3$.

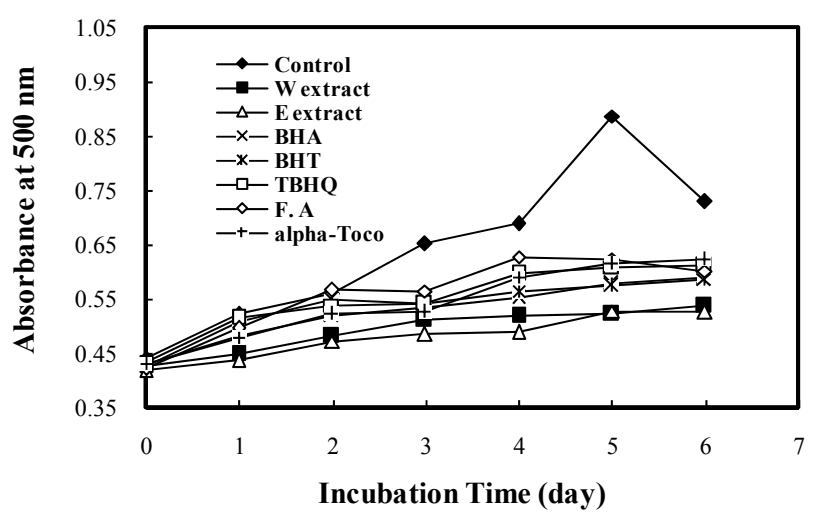

Figure 7. Absorbance of the dried boxthorn fruit (Lycium chinensis) extracts and commercial antioxidants on the linoleic acid peroxidation measured by the thiocyanate method.
Table 2. Inhibition percentage of peroxide formation in the presence of dried boxthorn fruit (Lycium chinensis) extracts as compared with commercial antioxidant at $5 \mathrm{~d}$ of linoleic acid peroxidation.

\begin{tabular}{cc}
\hline Sample & $\begin{array}{c}\text { Inhibition of peroxide } \\
\text { formation }(\%)^{1}\end{array}$ \\
\hline W extract & $41.179 \pm 1.232 \mathrm{a}$ \\
E extract & $40.469 \pm 1.748 \mathrm{a}$ \\
BHA & $35.008 \pm 2.164 \mathrm{~b}$ \\
BHT & $35.396 \pm 0.754 \mathrm{~b}$ \\
TBHQ & $31.222 \pm 0.517 \mathrm{c}$ \\
FA & $29.643 \pm 0.905 \mathrm{c}$ \\
Alpha-Toco & $30.733 \pm 0.860 \mathrm{c}$ \\
\hline
\end{tabular}

${ }^{1}$ Each value is the mean \pm standard deviation; $\mathrm{n}=3$; Values with different letters in column are significantly different $(\mathrm{p}<0.05)$; $\mathrm{W}$ extract $=$ water extract; E extract $=$ ethanol extract; $\mathrm{BHA}=$ butylated hydroxyanisole; $\mathrm{BHT}$ $=$ butylated hydroxytoluene; TBHQ = tert-butylhydro quinone; $\mathrm{FA}=$ ferulic acid; Alpha-Toco $=\alpha$-tocopherol

extracts could be due to phenolic compounds as well as flavonoids present in the dried boxthorn fruit. This result is supported by several studies on medicinal plants in Turkey [47] and in Parkistan [48], which showed a significantly high lipid peroxidation by phenolic components. In addition, the data on the inhibition of linoleic acid peroxidation by oolong tea extract [49], which contain a variety of flavonoid compounds, reaffirmed the results of the present study. Free radicals are well known to play an important role in autoxidation of unsaturated lipids in foodstuffs [50]. On the other hands, antioxidants are believed to intercept the free radical chain oxidants, and to contribute hydrogen from the phenolic hydroxyl groups, thereby forming stable free radicals, which do not initiate or propagate further oxidation in food system with lipid [51]. This result demonstrated that the both $\mathrm{W}$ and $\mathrm{E}$ extracts from the dried boxthorn fruit are effective as hydrogen donor and as primary antioxidant by reacting with the lipid radical in an emulsion system with lipid.

\subsubsection{Inhibition Activity on Rat Erythrocyte Hemolysis}

Erythrocytes are easily exposed to oxidative hazard in biological system due to their specific role as oxygen carriers [52]. Under physiological conditions, ROS are rapidly removed by the endogenous defense systems; however, when ROS are overproduced or their endogenous defense systems are impaired, severe oxidative damages to plasma membrane and cytosolic components in biological system occur, eventually leading to hemolysis [53]. In the present study, the protective effect of dried boxthorn fruit extracts against the oxidative hemolysis of rat erythrocytes induced by AAPH, a peroxyl radical initiator, was investigated and compared with those of com- 
mercial antioxidants such as BHA, BHT, TBHQ, ferulic acid, and $\alpha$-tocopherol. A significant difference $(\mathrm{p}<0.05)$ was observed in the erythrocytes treated with $\mathrm{W}$ extract obtained from the dried boxthorn fruit, which showed greater protective effect against hemolysis of erythrocytes induced by AAPH, higher than those of commercial phenolic antioxidants such as BHA, BHT, TBHQ, ferulic acid, and $\alpha$-tocopherol (Figure 8). The order of the inhibition activity on hemolysis was as follows: $\mathrm{W}$ extract $>$ ferulic aicd $\geq$ BHA $>\alpha$-tocopherol $>$ BHT $>$ E extract $\geq$ TBHQ. Results of the present study showed the unclear relationship between the antioxidant activity and phenolic compounds in inhibiting the hemolysis of erythrocytes could be explained in numerous ways and suggested that the activity of phenolic antioxidants against the hemolysis mediated by AAPH could depend on the structure, concentration, number, and position of hydrogen-donating hydroxyl groups on the aromatic cycles of the phenolic molecules $[54,55]$. Furthermore, when the inhibition percentages of both $\mathrm{W}$ and $\mathrm{E}$ extracts obtained from the dried boxthorn fruit were compared, the E extract appeared to have relatively lower activity in the inhibition of hemolysis. Interestingly, the results of present study showed that even though $\mathrm{W}$ extract obtained from the dried boxthorn fruit appeared to possess higher antioxidative capacity than the $\mathrm{W}$ extract in preventing hemolysis of erythrocytes, it did not possess higher activity in scavenging $\mathrm{H}_{2} \mathrm{O}_{2}$ in the non-cellular system indicating that some necessary compounds found in only in $\mathrm{W}$ extract could prevent the effective protection against the hemolysis induced by AAPH as supported by $\mathrm{Li}$, et al. [56], who reported that polysaccharides extracted from boxthorn fruit strongly inhibited the AAPH [2,2'-azo-bis (2-amidinopropane) dihydrochloride]-induced hemolysis of erythrocytes.

\subsubsection{Inhibition Activity on Lipid Peroxidation of Rat Brain Tissue}

$\mathrm{Fe}^{2+}$ ion is well-known to stimulate lipid peroxidation within biological system, and the Fe-induced lipid peroxidation has been long-recognized as a potential mechanism of biological cell injury [57,58]. Lipid peroxidation involves the cleavage of polyunsaturated fatty acids at their double bonds, leading to the formation of MDA (malondialdehyde) in biological system [52]. The MDA serves as a convenient index for determining the extent of lipid peroxidation [59]. In the present study, the inhibition activity of dried boxthorn fruit extracts against $\mathrm{Fe}^{2+} /$ accorbate-induced lipid peroxidation on rat brain tissue was measured by the color intensity of MDA-TBA complex and compared with those of commercial antioxidants such as BHA, BHT, TBHQ, ferulic acid, and $\alpha$-tocopherol. No significant difference was found ( $\mathrm{p}>$ 0.05 ) between $\mathrm{W}$ and $\mathrm{E}$ extracts of dried boxthorn fruit, exhibiting $>85 \%$ inhibition activity of Fe-induced lipid peroxidation (Figure 9). The order of the inhibition activity was as follows: BHA $(95.913 \%) \geq$ BHT $(95.282 \%)$ $\geq$ TBHQ $(94.351 \%)>\alpha$-tocopherol $(89.748 \%) \geq \mathrm{W}$ extract $(88.408 \%) \geq$ E extract $(87.761 \%)>$ ferulic acid $(20.703 \%)$. Even though the inhibition percentages on Fe-induced lipid peroxidation of both extracts obtained from the dried boxthorn fruit are slightly lower than those of synthetic antioxidants such as BHA, BHT, and TBHQ, both extracts could be considered to have a potent antioxidant activity, possibly due to some phenolic compounds affecting the Fe-induced lipid peroxidation. Lipid peroxidation in bio-

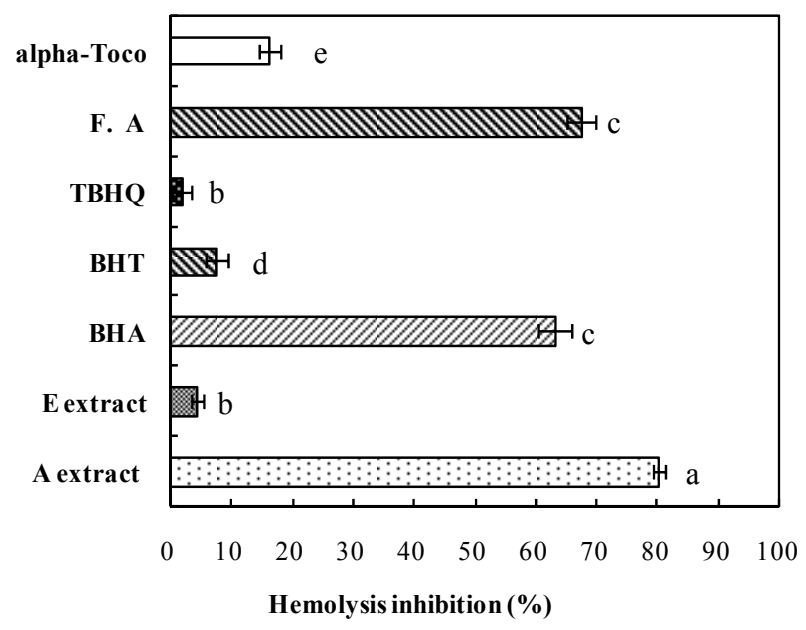

Figure 8. Comparison of inhibition activities between the dried boxthorn fruit (Lycium chinensis) extracts and commercial antioxidants on the hemolysis of erythrocyte initiated by APPH. Bars with different letters are significantly different $(p<0.05) ; n=3$.

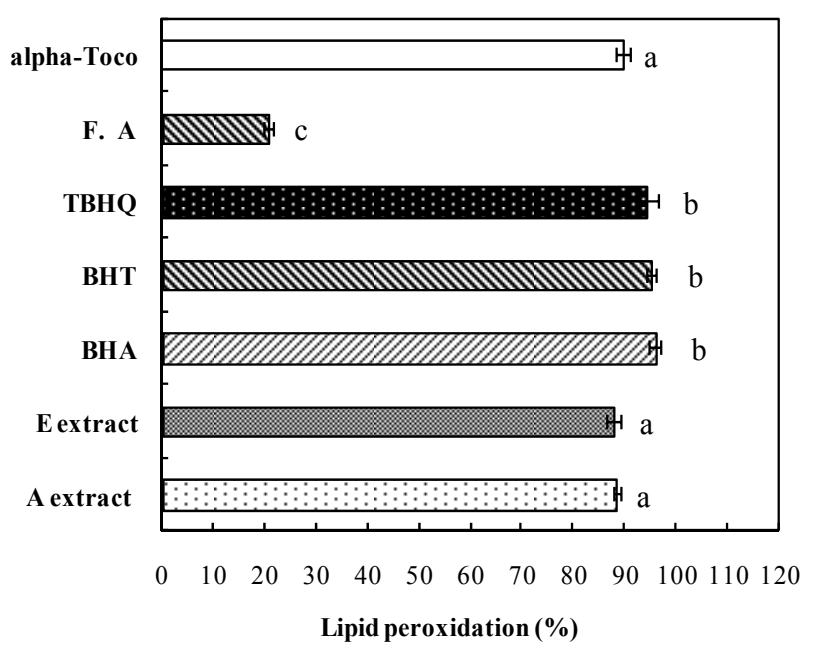

Figure 9. Comparison of inhibition activities between the dried boxthorn fruit (Lycium chinensis) extracts and commercial antioxidants by $\mathrm{Fe}^{2+} /$ Ascorbate-induced lipid peroxidation of rat brain tissue. Bars with different letters are significantly different $(p<0.05) ; n=3$. 
logical system is a complex process, which involves formation and propagation of lipid radicals, uptake of oxygen, rearrangement of the double bonds in unsaturated lipid, and the eventual destruction of membrane lipids, and finally resulting in the breakdown of products such as MDA in microsomes of biological system [60]. Our data suggest that the extracts could be a potential source of radical scavengers in inhibiting metal-induced lipid peroxidation in biological system $[61,62]$ as well as break the chain reaction of lipid peroxidation by rapid donation of electrons to lipid peroxyl radicals, terminating the chain reaction by forming a corresponding radical that is less reactive than the peroxyl radical, thereby slowing the process of peroxidation [27]. Tocopherol is an example of a chain-breaking antioxidant, as evidenced by the regeneration of tocopherol from its radical by ascorbic acid in vitro [63]. This result indicated that phenolic and flavonoid compounds present in both $\mathrm{W}$ and $\mathrm{E}$ extracts, as based on the relationship data of total phenolics and flavonoids and antioxidant activity suggested previously (Figures 2-5), could contribute to the protective activity against metal-induced lipid peroxidation in cellular system.

\section{Conclusion}

Both extracts obtained from the dried boxthorn (Lycium chinensis) fruit showed strong antioxidant activities in a concentration-dependent mode, which was linearly correlated with increasing total phenolics and flavonoid content. The antioxidant activities of both extracts were maximized at the concentration of $3200 \mathrm{ppm}$ with total phenolics of $86.365 \mathrm{ppm}(\mu \mathrm{g} / \mathrm{ml})$. The antioxidant activities of both extracts (W and E extract) were compared with those of well-known commercial phenolic antioxidants such as BHA, BHT, TBHQ, ferulic acid, and $\alpha$-tocopherol at $86.365 \mathrm{ppm}(\mu \mathrm{g} / \mathrm{ml})$ using various parameters. In the $\mathrm{H}_{2} \mathrm{O}_{2}$ scavenging activity, E extract had a significantly high activity comparable with that of ferulic acid, whereas $\mathrm{W}$ extract showed a lower activity. In the inhibition activity of peroxide formation by linoleic acid peroxidation, no significant difference $(p>0.05)$ was found between $\mathrm{W}$ and $\mathrm{E}$ extracts, and both extracts showed a relatively higher activity compared to the commercial antioxidants. In the antioxidant assays using cellular system, $\mathrm{W}$ extract exhibited a significant power in inhibiting the hemolysis of rat erythrocytes induced by peroxyl radicals, whereas none was shown in $\mathrm{E}$ extract. In the $\mathrm{Fe}^{2+}$-induced lipid peroxidation using rat brain tissue, no significant difference $(p>0.05)$ was found between both extracts, they showed activities comparable to those of synthetic antioxidants. The results of the present study show that both $\mathrm{W}$ and $\mathrm{E}$ extracts of dried boxthorn (Lycium chinensis) fruit can be used as easily accessible source of natural antioxidants in food industry, replacing the synthetic antioxidants, and as a possible functional supplement in pharmaceutical industry. However, identification and quantification of exact bioactive components responsible for the antioxidant activity in both $\mathrm{W}$ and $\mathrm{E}$ extracts have not yet been elucidated. Therefore, future researches should be focused on the identification and quantification of individual bioactive components having the maximum activity in both $\mathrm{W}$ and $\mathrm{E}$ extracts to satisfy the recent consumer needs, which can be fitted into the well-being concept pursuing the use of naturally-occurring medicinal plants.

\section{REFERENCES}

[1] J. V. Higdon and B. Frei, "Tea Catechins and Polyphenols: Health Effects, Metabolism, and Antioxidant Functions," Critical Reviews in Food Science and Nutrition, Vol. 43, No. 1, 2003, pp. 89-143. doi: $10.1080 / 10408690390826464$

[2] K. Le, F. Chiu and K. Ng, "Identification and Quantification of Antioxidants in Fructus lycii," Food Chemistry, Vol. 105, No. 1, 2007, pp. 353-363. doi:10.1016/i.foodchem.2006.11.063

[3] W. Droge, "Free Radicals in the Physiological Control of Cell Function," Physiological Reviews, Vol. 82, No. 1, 2002, pp. 47-95.

[4] İ. Gülçin, M. Oktay, Ö. İ. Küfrevioğlu and A. Alsan, "Determination of Antioxidant Activity of Lichen $\mathrm{Ce}$ traria islandica (L.) Ach," Journal of Ethnopharmacology, Vol. 79, No. 3, 2002, pp. 325-329. doi:10.1016/S0378-8741(01)00396-8

[5] İ. Gülçin, M. Oktay, E. Kıreçc1 and Ö. İ. Kğfrevioğlu, "Screening of Antioxidant and Antimicrobial Activities of Anise (Pimpinella anisum L.) Seed Extracts," Food Chemistry, Vol. 83, No. 3, 2003, pp. 371-382. doi:10.1016/S0308-8146(03)00098-0

[6] A. Barbouti, P. T. Doulias, L. Nousis, M. Tenopoulou and D. Galaris, "DNA Damage and Apoptosis in Hydrogen Peroxide-Exposed Jurkat Cells: Bolus versus Contious Generation of $\mathrm{H}_{2} \mathrm{O}_{2}$," Free Radical Biology and Medicine, Vol. 33, No. 5, 2002, pp. 691-702. doi:10.1016/S0891-5849(02)00967-X

[7] S. Linn, "DNA Damage by Iron and Hydrogen Peroxide in Vitro and in Vivo," Drug Metabolism Reviews, Vol. 30, No. 2, 1998, pp. 313-326. doi: $10.3109 / 03602539808996315$

[8] S. Sasaki, T. Ohta and E. A. Decker, "Antioxidant Activity of Water-Soluble Fraction of Salmon Spremary Tissue," Journal of Agricultural and Food Chemistry, Vol. 44, No. 7, 1996, pp. 1682-1686. doi:10.1021/jf950778h

[9] P. D. Duh, "Antioxidant Activity of Burdock (Arctium lappa Linne): Its Scavenging Effect on Free Radical and Active Oxygen," Journal of the American Oil Chemists' Society, Vol. 75, No. 4, 1998, pp. 455-465.

[10] L. Brave, "Polyphenols: Chemistry, Dietary Sources, Metabolism, and Nutritional Significance," Nutrition Reviews, Vol. 56, No. 11, 1988, pp. 317-333. 
doi:10.1111/j.1753-4887.1998.tb01670.x

[11] M. S. Su, Y. T. Shyu and P. J. Chien, "Antioxidant Activities of Citrus Herbal Product Extracts," Food Chemistry, Vol. 111, No. 4, 2008, pp. 892-896. doi:10.1016/j.foodchem.2008.05.002

[12] N. Ito, S. Fukushima, A. Hasegawa, M. Shibata and T. Ogiso, "Carcinogenecity of Buthylated Hydroxyl Anisole in F344 Rats," Journal of the National Cancer Institute, Vol. 70, No. 2, 1983, pp. 343-347.

[13] W. Zheng and S. Y. Wang, "Antioxidant Activity and Phenolic Compounds in Selected Herbs," Journal of Agricultural and Food Chemistry, Vol. 49, No. 11, 2001, pp. 5165-5170. doi:10.1021/jf010697n

[14] W. A. Pryor, "The Antioxidant Nutrient and Diseases Prevention-What Do We Know and What Do We Need to Find Out?" The American Journal of Clinical Nutrition, Vol. 53, No. 1, 1991, pp. 391-393.

[15] J.-S. Kim and H. Y. Chung, "GC-MS Analysis of the Volatile Components in Dried Boxthorn (Lycium chinenesis) Fruit," Journal of the Korean Society for Applied Biological Chemistry, Vol. 52, No. 5, 2009, pp. 516-524. doi:10.3839/jksabc.2009.088

[16] O. Potterat, "Goji (Lycium barbarum and L. chinense): Phytochemistry, Pharmacology, and Safety in the Perspective of Traditional Uses and Recent Popularity," Planta Medica, Vol. 76, No. 1, 2010, pp. 7-19.

[17] S. Y. Kim, Y. H. Choi, J. Kim, Y. C. Kim and H. S. Lee, "New Antihepatoxic Cerebrocide from Lycium chinense Fruits," Journal of Natural Product, Vol. 60, No. 3, 1997, pp. 274-276. doi:10.1021/np960670b

[18] X. Peng and G. Tian, "Structural Characterization of the Glycan Part of Glycoconjugate LbGp2 from Lycium barbarum L.," Carbohydrate Research, Vol. 331, No. 1, 2001, pp. 95-99. doi:10.1016/S0008-6215(00)00321-9

[19] I. Leung, M. Tso, W. Li and T. Lam, "Absorption and Tissue Distribution of Zeaxanthin and Lutein in Rhesus Monkeys after Taking Fructus lycii (Gou Qi Zi) Extract," Investigate Ophthalmology and Visual Science, Vol. 42, No. 2, 2001, pp. 466-471.

[20] T. Toyoda-Ono, M. Maeda, M. Nakao, M. Yoshimura, N. Sigiura-Tomimori and H. Fukami, "2-O( $\alpha$-D-glucopyranosyl) Ascorbic Acid, a Novel Ascorbic Acid Analogue Isolated from Lycium Fruit," Journal of Agricultural and Food Chemistry, Vol. 52, No. 7, 2004, pp. 2092-2096. doi:10.1021/if035445w

[21] S. Y. Kim, E. J. Lee, H. P. Kim, Y. C. Kim, A. Moon and Y. C. Kim, "A Novel Cerebrocide from Lycii Frctus Preserves the Hepatic Glutathione Redox System in Primary Cultures of Rat Hepatocytes," Biological and Pharmaceutical Bulletin, Vol. 22, No. 8, 1999, 873-875. doi:10.1248/bpb.22.873

[22] K. T. Ha, S. J. Yoon, D. Y. Choi, D. W. Kim, J. K. Kim and C. H. Kim, "Prospective Effect of Lycium chinense Fruit on Carbon Tetrachloride-Induced Hepatotoxicity," Journal of Ethnopharmacology, Vol. 96, No. 3, 2005, pp. 529-535. doi:10.1016/j.jep.2004.09.054

[23] J. C. Tang, J. N. Zhang, Y. T. Wu and Z. K. Li, "Effect of the Water Extract and Ethanol Extract from Traditional
Chinese Medicines Angelica sinensis (Oliv.) Diels, Ligusticum chuanxiong Hort. and Rheum palmatum L. on Rat Liver Cytochrome P450 Activity," Phytotherapy Research, Vol. 20, No. 12, 2006, pp. 1046-1051. doi:10.1002/ptr.1974

[24] J.-S. Kim, "Radical Scavenging Capacity and Antioxidant Activity of the E Vitamer Fraction in Rice Bran," Journal of Food Science, Vol. 70, No. 3, 2005, pp. C208-C213. doi:10.1111/j.1365-2621.2005.tb07127.X

[25] T. Hatano, H. Kagawa, T. Yasuhara and T. Okuda, "Two New Flavonoids and Other Constituents in Licorice Root: Their Relative Astringency and Radical Scavenging Effects," Chemical and Pharmaceutical Bulletin, Vol. 36, No. 6, 1988, pp. 2090-2097. doi:10.1248/cpb.36.2090

[26] R. Julkunen-Tiitto, "Phenolic Contents in the Leaves of Northern Willows: Methods for the Analysis of Certain Phenolics," Journal of Agricultural Food Chemistry, Vol. 33, No. 2, 1985, pp. 213-217. doi:10.1021/jf00062a013

[27] S. N. Lim, P. C. K. Cheung, V. E. C. Ooi and P. O. Ang, "Evaluation of Antioxidative Activity of Extracts from a Brown Seaweed, Sargassum siliquastrum," Journal of Agricultural and Food Chemistry, Vol. 50, No. 13, 2002, pp. 3862-3866. doi:10.1021/jf020096b

[28] D. Atmani, N. Chaher, M. Berboucha, K. Ayouni, H. Lounis, H. Boudaoud, N. Debbache and D. Atmani, "Antioxidant Capacity and Phenol Content of Selected Algerian Medicinal Plants," Food Chemistry, Vol. 112, No. 2, 2009, pp. 303-309. doi:10.1016/j.foodchem.2008.05.077

[29] Z. Marksimović, D. Malenčić and N. Kovačević, "Polyphenol Contents and Antioxidant Activity of Maydis stigma Extracts," Bioresource Technology, Vol. 96, No. 8, 2005, pp. 873-877. doi:10.1016/j.biortech.2004.09.006

[30] M. Oyaizu, "Studies on Product of Browning Reaction Prepared from Glucose Amine," Japanese Journal of $\mathrm{Nu}$ trition, Vol. 44, No. 6, 1986, pp. 307-315. doi:10.5264/eiyogakuzashi.44.307

[31] G. C. Yen, Y. C. Chang and S. W. Su, "Antioxidant Activity and Active Compounds of Rice Koji Fermented with Aspergillus candidus," Food Chemistry, Vol. 83, No. 1, 2003, pp. 49-54. doi:10.1016/S0308-8146(03)00035-9

[32] L. M. Cheung, P. C. K. Cheung and V. E. C. Ooi, "Antioxidnat Activity and Total Phenolics of Edible Mushroom Extracts," Food Chemistry, Vol. 81, No. 2, 2003, pp. 249-255. doi:10.1016/S0308-8146(02)00419-3

[33] M. Miki, H. Tamina, M. Mino, Y. Yamamoto and E. Niki, "Free-Radical Chain Oxidation of Rat Red Blood Cells by Molecular Oxygen and Its Inhibition by $\alpha$-tocopherol," Archives of Biochemistry and Biophysics, Vol. 258, No. 2, 1987, pp. 373-380. doi:10.1016/0003-9861(87)90358-4

[34] K. Wang, Y. Zhang and C. Yang, "Antioxidant Phenolic Compounds from Rhizomes of Polygonum paleaceum," Journal of Ethnopharmacology, Vol. 96, No. 3, 2005, pp. 483-487. doi:10.1016/j.jep.2004.09.036

[35] O. P. Tiwari and Y. B. Triphathi, "Antioxidant Properties of Different Fractions of Vitex negundo Linn.," Food Chemistry, Vol. 100, No. 3, 2007, pp. 1170-1176. doi:10.1016/j.foodchem.2005.10.069 
[36] E. S. Abdel-Hameed, "Total Phenolic Contents and Free Radical Scavenging Activity of Certain Egyptian Ficus species Leaf Samples," Food Chemistry, Vol. 114, No. 4, 2009, pp. 1271-1277. doi:10.1016/j.foodchem.2008.11.005

[37] T. Yamaguchi, H. Takamura, T. Matoba and J. Terao, "HPLC Method for Evaluation of the Free Radical-Scavenging Activity of Foods by Using

1,1-diphe-nyl-2-picrylhydrazyl," Bioscience Biotechnology, and Biochemistry, Vol. 62, No. 8, 1988, pp. 12011204.

[38] A. Kumaran and J. Karunakaran, "In Vitro Antioxidant Activities of Methanol Extracts of Five Phyllanthus Species from India," LWT-Food Science and Technology, Vol. 40, No. 2, 2007, pp. 344-352. doi:10.1016/j.lwt.2005.09.011

[39] C. Wong, H. Li, K. Cheng and F. Chen, "A Systematic Survey of Antioxidant Activity of 30 Chinese Medicinal Plants Using the Ferric Reducing Antioxidant Power Assay," Food Chemistry, Vol. 97, No. 4, 2006, pp. 705-711. doi:10.1016/j.foodchem.2005.05.049

[40] H. Wang, G. Cao and R. L. Prior, "Total Antioxidant Capacity of Fruits," Journal of Agricultural and Food Chemistry, Vol. 44, No. 3, 1996, pp. 701-705. doi:10.1021/jf950579y

[41] G. Cao, E. Sofic and R. L. Prior, "Antioxidant and ProOxidant Behavior of Flavonoids: Structure-Activity Relationships," Free Radical Biology and Medicine, Vol. 22, No. 5, 1997, pp. 749-760. doi:10.1016/S0891-5849(96)00351-6

[42] S. Mier, J. Kanner, B. Akiri and S. P. Hadas, "Determination and Involvement of Aqueous Reducing Compounds in Oxidative Defense Systems of Various Senescing Leaves," Journal of Agricultural and Food Chemistry, Vol. 43, No. 7, 1995, pp. 1813-1817. doi:10.1021/if00055a012

[43] C. Rice-Evans, N. J. Miller and G. Paganga, "StructureAntioxidant Activity Relationship of Flavonoids and Phenolic Acids," Free Radical Biological and Medicine, Vol. 20, No. 7, 1996, pp. 933-956. doi:10.1016/0891-5849(95)02227-9

[44] G. Topçu, M. Ay, A. Bilici, C. Sarikurkcu, M. Ozturk and A. Ulubelen, "A New Flavone from Antioxidant Extracts of Pistacia terebinthus," Food Chemistry, Vol. 103, No. 3, 2007, pp. 816-822. doi:10.1016/j.foodchem.2006.09.028

[45] B. Halliwell, "Reactive Oxygen Species in Living Systems: Source, Biochemistry, and Role in Human Disease," The American Journal of Medicine, Vol. 91, No. 3, 1991, pp. 14-22. doi:10.1016/0002-9343(91)90279-7

[46] M. Ismail, E. Manickam, A. Danial, A. Rahmat and A. Yahaya, "Chemical Composition and Antioxidant Activity of Strobilanthes crispus Leaf Extract," Journal of $\mathrm{Nu}$ tritional Biochemistry, Vol. 11, No. 11, 2000, pp. 536542. doi:10.1016/S0955-2863(00)00108-X

[47] B. Tepe, M. Sokmen, H. A. Akpulat, O. Yumrutas and A. Sokmen, "Screening of Antioxidative Properties of the Methanolic Extracts of Pelargonium endlicherianum Fenzl., Verbascum wiedemannianum Fisch. \& Mey.,
Sideritis libanotica Labill. Subsp. linearis (Bentham) Borm., Centaurea mucronifera DC. and Hieracium cappadocicum Freyn from Turkish flora," Food Chemistry, Vol. 98, No. 1, 2006, pp. 9-13. doi:10.1016/j.foodchem.2005.05.046

[48] B. Sultana, F. Anwar and R. Przybylski, "Antioxidant Activity of Phenolic Components Present in Barks of Azadirachta indica, Terminalia arjuna, Aacacia nilotica, and Eugenia jambolana Lam, Trees," Food Chemistry, Vol. 104, No. 3, 2007, pp. 1106-1114. doi:10.1016/j.foodchem.2007.01.019

[49] G. C. Yen and H. Y. Chen, "Comparison of Antimutagenic Effect of Various Tea Extracts," Journal of Food Protection, Vol. 57, No. 1, 1994, pp. 54-58.

[50] H. Kaur and J. Perkins, "The Free Radical Chemistry of Food Additives,” In: O. I. Aruoma and B. Halliwell, Eds., Free Radicals and Food Additives, Taylor and Francis, London, 1991, pp. 17-35.

[51] J. D. Dziezak, "Preservatives: Antioxidants. The Ultimate Answer to Oxidation," Food Technology, Vol. 40, No. 9, 1986, pp. 94-102.

[52] C. Manna, S. D’Angelo, V. Migliardi, E. Loffredi, M. Orazio, P. Morrica, P. Galletti and V. Zappia, "Protective Effect of the Phenolic Fraction from Virgin Olive Oils against Oxidative Stress in Human Cells," Journal of Agricultural and Food Chemistry, Vol. 50, No. 22, 2002, pp. 6521-6526. doi:10.1021/jf020565+

[53] C. Manna, P. Galletti, V. Cucciolla, G. Montedoro and V. Zappia, "Oilve Oil Hydroxy-Tyrosol Protectsd Human Erythrocytes against Oxidative Damages," Journal of $\mathrm{Nu}$ tritional Biochemistry, Vol. 10, No. 3, 1999, pp. 159-165. doi:10.1016/S0955-2863(98)00085-0

[54] E. J. Liens, S. Ren, H. H. Bui and R. Wang, "Quantitative Structure-Activity Relationship Analysis of Phenolic Antioxidant," Free Radical Biology and Medicine, Vol. 26, No. 3, 1999, pp. 285-294. doi:10.1016/S0891-5849(98)00190-7

[55] A. Djeridane, M. Yousfi, B. Nadjemi, D. Boutassouna, P. Stocker and N. Vidal, "Antioxidant Activity of Some Algerian Medicinal Plants Extracts Containing Phenolic Compounds," Food Chemistry, Vol. 97, No. 4, 2006, pp. 654-660. doi:10.1016/j.foodchem.2005.04.028

[56] X. Li, X. L. Li and A. G. Zhou, "Evaluation of Antioxidant Activity of the Polysaccharides Extracted from $\mathrm{Ly}$ cium barbarum Fruits in Vitro," European Polymer Journal, Vol. 43, No. 2, 2007, pp. 488-497. doi:10.1016/j.eurpolymi.2006.10.025

[57] H. Esterbauer, H. Zollner and R. J. Schaur, "Hydroxyalkenals Cytotoxic Products of Lipid Peroxidation," ISI Altas of Science-Biochemistry, Vol. 1, No. 4, 1988, pp. 311317.

[58] C. E. Vaca, P. Vodicka and K. Hemminki, "Determination of Malonaldehyde-Modified 2'-deoxyguanosine-3'-monophosphate and DNA by ${ }^{32}$ P-postlabelling," Carcinogenesis, Vol. 13, No. 4, 1992, pp. 593-599. doi:10.1093/carcin/13.4.593

[59] F. Liu, V. E. C. Ooi and S. T. Chang, "Free Radical Scavenging Activities of Mushroom Polysaccharide Extracts," 
Life Science, Vol. 60, No. 10, 1997, pp. 763-771.

doi:10.1016/S0024-3205(97)00004-0

[60] B. A. Igor, I. D. Anatolli, V. B. Aleksander, A. K. Valadimer and I. P. Alla, "Chelating and Free Radical Scavenging Mechanisms of Inhibiting Action of Rutin and Quercetin in Lipid Peroxidation," Biochemical Pharmacology, Vol. 38, No. 11, 1989, pp. 1763-1769. doi:10.1016/0006-2952(89)90410-3

[61] J. M. Braughler, L. A. Duncan and R. L. Chase, "The Involvement of Iron in Lipid Peroxidation," Journal of
Biological Chemistry, Vol. 262, No. 22, 1986, pp. 1028210289.

[62] L. M. Cheung and P. C. K. Cheung, "Mushroom Extracts with Antioxidant Activity against Lipid Peroxidation," Food Chemistry, Vol. 89, No. 3, 2005, pp. 403-409. doi:10.1016/j.foodchem.2004.02.049

[63] B. Frei, "Natural Antioxidative in Human Health and Disease," Academic Press, San Doego, 1994, pp. 1-62. 